\title{
C. G. Jung's Memories, Dreams, Reflections as a Source for Doris Lessing's Briefing for a Descent into Hell
}

\author{
Matthew Fike, Ph.D.* \\ Winthrop University
}

\begin{abstract}
Doris Lessing was conversant in Jungian psychology, and her novel Briefing for a Descent into Hell includes more Jungian elements than previous critics have identified. In particular, it is likely that she borrowed from Jung's Memories, Dreams, Reflections when crafting her protagonist Charles Watkins's descent into madness and return to sanity. This essay argues that the autobiography's chapter 6, "Confrontation with the Unconscious," and chapter 10, "Visions"-Jung's encounter with madness and his near-death experience-provided Lessing with not only a successful nekyia by which to evaluate Watkins's less successful inner journey but also a series of images that she reworked in the novel. Considered in light of MDR, Briefing conveys a sense of lost potential: Watkins regains his memory but, unlike Jung, forgets his vision of the collective unconscious.
\end{abstract}

\section{Introduction}

When James Hillman states, "We have no myths of the nekyia [descent into the underworld or the collective unconscious] . . . Dante's underworld was our culture's last, and it was imagined even before the Renaissance had properly begun" (64), one may be forgiven for raising an eyebrow. Two obvious exceptions are Herman Melville's Moby-Dick, which Edward F. Edinger considers an American nekyia, and Joseph Conrad's Heart of Darkness, for both describe a descent into the unconscious. One must also acknowledge C. G. Jung's The Red Book as a nekyia, for as R. F. C. Hull says of the time period it records, "Jung was a walking asylum in himself, as well as its head physician" and "went through everything an insane person goes through" (qtd. in van der Berk 74). A summary of his inner experiences appears in "Confrontation with the Unconscious," chapter 6 in Memories, Dreams, Reflections, and chapter 10 describes his near-death experience (NDE). Although there is no record of which Jungian texts Doris Lessing read, her novel Briefing for a Descent into Hell includes enough parallels to suggest that she had Jung's visions and NDE in mind when crafting the novel (the English translation of $M D R$ was published in 1961, Lessing's novel in 1971). The purpose of this essay, then, is to suggest that Memories, Dreams, Reflections provided Lessing with a successful nekyia, a hero's journey into the mind, by which to measure the experiences of the protagonist, Professor Charles Watkins. Ultimately, his encounter with the unconscious, though compensatory, is unlike Jung's nekyia in not effecting change in his conscious life; therefore, rather than achieving a lasting wholeness in which the unconscious informs waking life through imaginal ways of knowing, Watkins rejects the fruits of the unconscious by reaffirming rationality and the limits of conscious awareness.

\section{Summary of the novel}

Briefing for a Descent into Hell takes place in 1969 and is written in two parts. In part one, British police find Charles Watkins in a state of total amnesia near the Waterloo Bridge after he has been robbed of his wallet. They take him to the Central Intake Hospital where he is cared for by Doctors X., whom he cannot see, and Y., who favors drugs over electroshock therapy. As he sleeps in the hospital, he experiences an apparently windless

\footnotetext{
** Author contact: fikem@winthrop.edu
} 
sailing journey in the northern Atlantic Ocean where he and eleven companions drift with the clockwise currents. After those eleven are taken up by a crystal UFO, he makes a raft and leaves behind the ship (he cannot handle it alone), trusting that he can reach the anti-clockwise currents in the southern hemisphere, and so he does. When the raft breaks up, he rests on a rock and eventually makes landfall in Brazil with the help of a porpoise. Watkins enters an Edenic forest where he is completely alone like Adam in the Garden and where the animals are at peace with each other. Hiking up to a plateau, he finds a savannah, eventually discovers the ruins of an ancient city, and cleans a large circle within the city's central square to provide a landing space for the crystal. Becoming moonstruck, he joins three women in eating bloody meat. A bit later, "rat-dogs" and apes battle each other, and the rat-dogs also fight each other (for example, a female rat-dog must protect her young against their own species). ${ }^{1}$ Eventually, when a large white bird takes Watkins on its back, he sees, among other sights, the coast of Portugal. The crystal then takes him up into a higher plane of existence where he sees the patterns that underlie things in the physical world and views Earth from outer space. Finally, he witnesses a conference of the classical gods where Mercury provides a prenatal briefing to those who are about to descend into physical bodies. They are instructed to remember their "brainprints" (125)—because amnesia often accompanies incarnation—and to deliver a message of harmony and unity. ${ }^{2}$ After watching his own birth and life up to the sleepless nights that preceded his breakdown, Watkins wakes up in the hospital, having experienced ocean, land, Crystal, and briefing.

Part two is largely epistolary. The letters help Doctors X. and Y. piece together the details of Watkins's life. Watkins is the fifty-year-old star of the Cambridge University classics department; the husband of Felicity, who is fifteen years younger and was once his student; the father of two sons with Felicity and one with Constance Maine, his former mistress (another former student who now hates him); and a veteran of World War II who saw combat in Africa and Italy. He is not a very nice person. Although professionally successful, he is egocentric and has little warmth for other people. The letters that convey this information vary greatly in length. There are fairly short letters from himself, Felicity, Constance, his department chair Jeremy Thorne, and men with whom he served in the war (notably his comrade Miles Bovey). There is a very long letter from a retired headmistress named Rosemary Baines who relates her highly positive reaction to his public lecture on educational reform. In that same letter, she explains that her friend Frederick Larson, an archeologist who has traveled extensively, experienced some of the same symptoms as Watkins himself prior to the breakdown. When Doctor Y. encourages Watkins to write down some of his experiences in an attempt to remember, he pens two documents-an account of parachuting into Yugoslavia to help the Partisans' effort against the Nazis and a description of the comingling of honeysuckle and camellia outside his residence hall room at college. The Yugoslavian episode, which includes falling in love with Konstantina Ribar, is apparently an imaginal embellishment of Bovey's wartime experience. Around the time he writes the Yugoslav narrative, Watkins makes friends with a twenty-one-year-old schizophrenic named Violet Stoke, who resembles Konstantina and arouses some of the male patients by not wearing panties. They consider leaving the hospital to live together, a plan discouraged by Doctor Y. Finally, in hopes of remembering the content of the briefing more fully, Watkins - to the horror of Violet and the other patients - submits to electroshock therapy. Ironically, he regains his memory of his former life but loses all memory of his visionary experience. As the novel ends, he writes to assure Thorne that he is fit to deliver his previously scheduled lectures on The Iliad.

\section{Lessing and Jung}

The previous criticism on Briefing has examined three main strands of influence: Sufism, R. D. Laing, and Jung. Lessing's debt to Sufism, which has been previously documented, need not concern us here. ${ }^{3}$ Laing's The Politics of Experience, however, is more directly relevant. He and Lessing, as Carole Klein points out (195, 204), were both interested in the expansion of consciousness and in the possibility that madness can provide psychological healing. Lessing denies the latter position in Walking in the Shade, saying that she never believed "that to go mad is to receive the ultimate in revelation" (276). She also denies that Laing's book influenced her at all. In a letter to Roberta Rubenstein, she writes: "I have not taken Laing as my starting point. I had not read the 
piece in question by him, or the book The Politics of Experience." She also claims that she found the name Watkins in the phone book (Rubenstein, Vision 196-97). Various critics consider Lessing's claims to be a mystification. For example, Marion Vlastos states that "it is hard to believe that Charles and the sculptor Jesse [Watkins], whose [schizophrenic] experience Laing records, have the same last name out of pure coincidence" (253). ${ }^{4}$ Despite the enigma of Lessing's conscious intention, the two characters' visions both depict the broad outline of human evolution. Laing sums up Jesse's experience “as going further 'in,' as going back through one's personal life, in and back and through and beyond into the experience of all mankind, of the primal man, of Adam and perhaps even further into the beings of animals, vegetables and minerals” (87). It is exactly so with Charles. The two characters, however, return to normalcy in different ways. Whereas electric shock jolts Charles back to reality but deprives him of any memory of the unconscious realm, Jesse is able to describe his inner journey into Laing's tape recorder. For Jesse, then, the journey is a "natural healing process" of moving "from ego to self." "Can we not see," Laing adds, "that this voyage is not what we need to be cured of, but that it is itself a natural way of healing our own appalling state of alienation called normality?” (88, 93, 116; emphases in the original).

Since Jung is considered Lessing’s psychological “mentor” (Rubenstein, Vision 9), various Jungian concepts are relevant to Briefing. ${ }^{5}$ For example, Lorelei Cederstrom states that Watkins, who aligns with masculine logos, has an archetypal vision of the Self that underscores the importance of feminine eros $(13,135,138)$. Strangely, Cederstrom does not specifically mention the anima in her chapter on the novel and seems unaware that the anima, which personifies the unconscious, is a psychopomp. All studies, however, concur that Watkins's unconscious compensates for his conscious life. A statement regarding compensation in Jung's chapter "Anima and Animus" is relevant here: "The repression of feminine traits and inclinations naturally causes these contrasexual demands to accumulate in the unconscious"; then "[t]he anima, being of feminine gender, is exclusively a figure that compensates the masculine consciousness"; so that "the man has, floating before him, in clear outlines, the alluring form of a Circe or a Calypso" (CW 7, par. 297, 328, 338). The Homeric references are particularly apt because Lessing casts Watkins not only as a modern Everyman, as critics have observed, but also as a modern Odysseus who explores what the title page calls "Inner-space fiction[.] For there is never anywhere to go but in.” Inner space is the realm of the anima.

Klein states that "Doris Lessing would briefly examine the ideas of Carl Jung” (110), but how much Jungian psychology did Lessing actually know? Her first exposure to Jung was probably in discussions that she and her second husband, Gottfried Lessing, had among friends. Someone in this group told her that Jung was one "of the main influences of our time,” but she herself wondered if Freud and Jung were passing phenomena (Under 336). Her several years of twice- or thrice-weekly sessions with a Jungian therapist, Mrs. Toni Sussman, in London were a more significant influence. Sussman's approach was eclectic, but Lessing “didn’t care about ideologiesFreud, Jung, and so forth"; "hated the labels”; and disliked Sussman's creedal interpretations because she, Doris, "had always been at home in these [psychological] realms" (Walking 147, 39-40). Perhaps her most critical statement about Jung comes in a letter to Rubenstein:

I think Jung's views are good as far as they go, but he took them from Eastern philosophers who go much further. Ibn El Arabi and El Ghazzali, in the [M]iddle [A]ges, had more developed ideas about the "unconscious," collective or otherwise, than Jung, among others. He was a limited man. But useful as far as he went. Both Jung and Freud were useful as far as they went. (Rubenstein, Vision 230-31)

The statement is not entirely fair-minded because Lessing agrees with Jung on numerous points and illustrates many Jungian concepts in her fiction. Most fundamentally, she embraces the idea that the mind is "above and beyond material conditions" (Howe 420). As Cederstrom notes, Lessing believes in the personal and collective aspects of the unconscious; in the archetypes, particularly shadow, anima/ animus, and the Self; ${ }^{7}$ in the confrontation with those archetypes as part of the individuation process; and in the idea that change within individual persons can spark societal change $(4,9-10,12-13,135)$. Lessing understands too that the 
unconscious compensates so that what is repressed manifests in unexpected and unacceptable ways (Klein 244), much as Jung believes that "when an inner situation is not made conscious, it happens outside as fate" (CW 9ii, par. 126). In addition, Lessing shares Jung's essentialism, specifically stating that "men and women are biologically programmed to want different things" (Walking 371). Dreams were especially important to her, especially “'Jungian dreams'-wonderful, those layers of ancient common experience” (Waking 40). In fact, she frequently relied on dreams to solve problems in her writing. So when she states that "I liked Jung, as all artists do" (Walking 39), she may be thinking of Jung's acknowledgement that "[t]he modern artist, after all, seeks to create art out of the unconscious" (MDR 195). ${ }^{8}$

Although Lessing considered Jung "a limited man," she absorbed many Jungian principles and employed them in her work. Critics and probably even Lessing herself, however, have not noticed the full extent of Briefing's use of Jungian concepts and imagery. There is, of course, commentary about mandala and quaternity images, but many examples have gone unnoticed. ${ }^{9}$ More significantly, no one mentions active imagination, abaissement du niveau mental (a lowering of the mental level), Jung's work on dementia praecox (schizophrenia), the link between schizophrenia and "big dreams," psychic functioning (psi), the primitive/archaic, UFOs, quantum physics, or the unus mundus. ${ }^{10}$ All of this Jungian material informs Briefing, and Lessing even selects as her protagonist a character whose initials, C. W., are the usual abbreviation for The Collected Works of C. G. Jung, though this is more likely a synchronicity for readers than an intentional move on her part. The web of Jungian connections implies that Briefing is not strictly a visionary upwelling of the psyche's "hinterlands” like H. Rider Haggard's She (CW 15, par. 137, 141-42) or a reflection of the author's personal unconscious but rather a book whose composition incorporates the zeitgeist. ${ }^{11}$ Watkins's experience is visionary, but Lessing assembled the novel from cultural fragments such as psychology, ufology, and evolution. The most significant omission from the scholarship, however, is the author's apparent borrowing of details from Memories, Dreams, Reflections regarding Jung's descent into madness and NDE.

\section{Jung's Memories, Dreams, Reflections}

In his autobiography Jung provides two examples of a successful nekyia or descent into the psychic underworld-his dreams and visions, which started less than a year before World War I, and a brush with death later in life. The many images common to Memories, Dreams, Reflections and Briefing for a Descent into Hell suggest that Lessing used Jung's work the way she may have used Jesse Watkins's account in Laing's Politics. If so, the autobiography provides a model for a successful encounter with the unconscious.

The white bird. Following his break with Freud, Jung finds himself in "a state of disorientation" and in late 1912 dreams of a white bird (a dove or seagull) that transforms into an eight-year-old blonde girl and then back into a bird, whereupon it says to him, "Only in the first hours of the night can I transform myself into a human being, while the male dove is busy with the twelve dead" (172). The passage introduces various images/motifs that can be found in Lessing's novel: a white bird, the anima, the land of the dead (the unconscious), and the number twelve. Rubenstein's comment on the child is instructive, though she is unaware of the image's autobiographical significance and is not writing about Briefing: "According to Jung, the appearance of the child archetype in individual psychic development is an anticipation of the synthesis of conscious and unconscious elements within the personality, as well as a symbol of healing, of wholeness, of opposites mediated" (Vision 223). In that spirit of wholeness, Jung considers the symbolism of the number twelve ("the twelve apostles, the twelve months of the year, the signs of the zodiac, etc."), the key point being that it represents the wholeness of a completed cycle. One may suspect that his reference to Hermes Trismegistos, who "was said to have left behind him a table upon which the basic tenets of alchemical wisdom were engraved in Greek," may refer to the twelve alchemical stages (MDR 172). Notably, Hermes/Mercury is the god who delivers the briefing in Lessing's novel.

In Briefing, the number twelve appears with surprising frequency and suggests the potential for lasting wholeness. Including Watkins, there are twelve people on the ship (19); the raft he makes of balsa wood is twelve by twelve (24); the white bird's wingspan "was ten or twelve feet" (80); when he gets taken up in the crystal, twelve days have passed in the real world (87); Watkins wonders, "what of Jupiter [the planet] with his 
—is it now twelve?—subsidiaries [moons]?” (108); and in Yugoslavia, “the band [of Partisans] remained in numbers between twelve and thirty" (209). These half dozen references to the number twelve parallel and reinforce Mercury's message of unity and harmony, primarily because of their association with the months of the year and their division into seasons. For Jung, "The seasons refer to the quartering of the circle which corresponds to the cycle of a year” ( $C W 12$, par. 283). Thus, the number twelve relates to his two favorite images of wholeness - the quaternity and the mandala.

World War. After seeing corpses and a city, Jung mentions several of his late works, including Flying Saucers: A Modern Myth of Things Seen in the Skies (172, 175). In 1913 he has a recurring precognitive vision of much of Europe engulfed by a sea of blood, a warning that world war was imminent (it broke out in the late summer of 1914). The city, the corpses, and UFOs have parallels in Briefing to the corpses of apes and rat-dogs that litter the city square, which Watkins tries to keep clear as a landing site for the crystal UFO that has taken up his friends from their sailing vessel. The battle between the apes and the rat-dogs appears to be his retrospective on World War II's manifestation of collective shadow versus the UFO's implication of wholeness.

The archetypes. Finally, in late 1913 Jung lets go-“"Then I let myself drop” (179)—and experiences the unfiltered power of the archetypal realm. He writes, "I plunged down into dark depths," much as Watkins and Bovey parachute into blackness over Yugoslavia in the former's false memory. Jung sees a corpse, more blood, "a glowing red crystal," and "an unknown brown-skinned man, a savage" who represents "the primitive shadow" (179-81). He next encounters Elijah and Salome, "Logos and Eros" (181-82), the same duality that characterizes Watkins's academic work and his visions, respectively. Jung now knows "that there is something in me which can say things that I do not know and do not intend, things which may even be directed against me" (183), much like the unconscious forces that cause stuttering in Watkins and Larson. Jung notes that the anima/soul plays a key role in the psychic life of men; that by writing down his visions he is really writing letters to her; that she can be positive or destructive; and that she is "the mouthpiece of the unconscious" (187), allowing unconscious information to reach conscious awareness. In other words, the anima provides "a bridge to the unconscious" (CW 13, par. 62). Significantly, the police find Watkins near the Waterloo Bridge, a symbol not only of transition but also of the anima's role in transporting unconscious content to conscious awareness.

Staying sane. Jung frankly acknowledges that his visions constitute "the same psychic material which is the stuff of psychosis and is found in the insane," a "matrix of a mythopoeic imagination which has vanished from our rational age" (188), yet he remains sane by several means. In addition to writing down his visions, he paints mandalas in his Black Book and later transfers them into what became The Red Book. His family and profession also help to ground him in the concrete world. Without these forces as a "counterpoise" (189) to his inner experiences, he would be psychologically at sea, which is where Watkins literally finds himself as the novel opens. Jung realizes, furthermore, that his visions carry an "ethical responsibility" (193) not to revert to his earlier persona. Instead, he chooses to withdraw from his academic position at the university in order to pursue further exploration of the unconscious. Watkins, of course, returns to his academic position.

At last, toward the end of World War I, the darkness begins to lift, and Jung's mandalas begin to reveal their meaning. They represent the wholeness and harmony of the Self, the path to individuation. Each one, he now realizes, is a cryptogram or microcosm of his psychic state on a given day. For example, a dream set in Liverpool includes both mandala and quaternity images, which resonate powerfully with Briefing. "The various quarters of the city were arranged radially around the square. In the center was a round pool, and in the middle of it a small island” (198). He is describing a mandala within a mandala within an image of quaternity within another image of quaternity. Similarly, in the center of the ancient city that Watkins discovers is a square with a circle within it, and within the circle, apparently, are signs of the zodiac (another twelve) - "geometrical patterns, that suggested flowers and gardens and their correspondence with the movements of the sky" (54). Here again are logos (the square) and eros (the circle), now brought into balance with each other in a both/and way that is so eerily similar to images in Memories, Dreams, Reflections as to suggest that Lessing's debt to Jung is greater than anyone has previously realized.

Near-death experience. Jung, like Laing and Lessing, is aware that a traumatic incident of one type or 


\section{Journal of Jungian Scholarly Studies}

\section{Vol. 11, No. 1, 2016}

another can trigger an inner journey. For Jesse, it is a dog bite; for Charles, a robbery; and for Jung, a broken foot and a heart attack. He nearly dies but instead of entering a tunnel of light, as in the classic NDE, he finds himself one thousand miles out in space, staring down at India and surrounding areas, much as Charles finds himself out in space, looking back at the Earth. Jung is summoned back to his physical body by his physician, Dr. H., who dies shortly thereafter. Watkins's doctors' names (X. and Y.) are also abbreviated, not to conceal identity as in Jung's case but to imply the insufficient rationality of the medical profession. The doctors are mathematical symbols of stark materialism masquerading as health-care providers. ${ }^{12}$

The hero's journey. Jung's dreams/visions and his NDE constitute a successful nekyia because, in each case, he does not resume his former persona but weaves the visionary material into his conscious life-he returns able to integrate the bounty of the unconscious. A successful descent requires proper integration as in Jung's experiences, which are a psychological version of the departure, descent, and return, which Joseph Campbell considers the hero's journey. Of course, the account of Jung's madness in Memories, Dreams, Reflections is a synthesis of the experiences that are recorded in The Red Book, whose comments on the descent into hell flesh out the anatomy of Jung's hero's journey. The beginning of his descent is marked by an either/or imbalance:

the spirit of this time does not leave a man and forces him to see only the surface, to deny the spirit of the depths and to take himself for the spirit of the times. The spirit of this time is ungodly, the spirit of the depths is ungodly, balance is godly. Because I was caught up in the spirit of this time [was unbalanced in favor of ratiocination], precisely what happened to me on this night had to happen to me, namely that the spirit of the depths erupted with force, and swept away the spirit of the time with a powerful wave. (TRB 238)

It is clear that Western scientific rationalism is at fault, for Jung states, "Keep it far from me, science that clever knower, that bad prison master who binds the soul and imprisons it in a lightless cell” (TRB 238). In William Blake's terms, the goal is to transcend the "single vision" of Western scientific rationalism (Newton and Locke) and to embrace visionary ways of knowing. ${ }^{13}$

In the middle stage of the journey, Jung and Watkins encounter the unconscious mind's compensatory impulse toward psychic balance. First, they both experience an abaissement du niveau mental, a lowering of the mental level that restricts the conscious personality. The lowering occurs when "the individual parts of the personality make themselves independent and thus escape from the control of the conscious mind, as in the case of anaesthetic areas or [like Watkins] systematic amnesias" (CW 9i, par. 213-14). Significantly, the lowering "can be the result of physical and mental fatigue, bodily illness, violent emotions, and shock [like the robbery]." Watkins's sleep-with sleep being in Jung's words a "more or less complete oblivion of the ego"-is also considered an abaissement ( $C W 3$, par. 523). Lessing seems to understand the value of sleep/dream in the selfhealing process when she writes about her own breakdown: "I needed to sleep and dream myself whole. I was full of division” (Under 297). Although one’s symptoms would lead a doctor to diagnose mental illness, Jung writes that "there is a divine [compensatory] madness [afoot] which is nothing other than the overpowering of the spirit of this time through the spirit of the depths" (TRB 238). The acknowledgement of the shadow is a second key element of the descent: "He who does not want evil will have no chance to save his soul from Hell. So long as he remains in the light of the upper world, he will become a shadow of himself. But his soul will languish in the dungeons of the daimons. This will act as a counterbalance that will forever constrain him” (TRB 289).

The result of confronting the shadow is a balanced psyche in which shadow lends its strength to consciousness and opposites become more complementary. That is, the goal of individuation is to achieve synthesis by collapsing the unconscious/conscious binary. ${ }^{14}$ As Jung states, "Depths and surface should mix so that new life can develop" (MDR 239). With regard to this idea, some of Lessing's critics are on the right track. Cederstrom notes that "the goal of individuation is to harmonize the known self with its darker unknown face, to make peace between the conscious personality and the powers of the unconscious" (8-9). Whittaker emphasizes that Lessing's concern in Briefing is to depict "a holistic approach to living that takes account of both the 
external, everyday life, and the internal psychic life of a character" (83). Or as Sanford L. Drob states in his commentary on The Red Book, there must be "dialectic" between visionary experience of the unconscious and conscious attention to reason (31).

All, however, have overlooked a passage in Briefing that deals with the shadow. Watkins and Doctor Y. have the following exchange:

DOCTOR Y. I'd like you to try something else, Professor. I'd like you to sit down and let yourself relax and try writing down anything that comes to you.

PATIENT. What sort of thing?

DOCTOR Y. Anything. Anything that might give us a lead in.

PATIENT. Ariadne's thread.

DOCTOR Y. Exactly so. But let's hope there is no Minotaur.

PATIENT. But perhaps he would turn out to be an old friend too? (200)

Their dialogue is easy allegory: Doctor Y. wants Watkins to use writing (active imagination) to draw memories up from the unconscious. Here the desired path leads into the depths, for that is where his forgotten memories now reside. The anima, as Ariadne, provides the thread, the necessary linkage, which like a telephone wire allows the unconscious to talk to the conscious mind. Doctor Y. is pleasantly apprehensive about what might come up because Watkins may encounter not just any monster but the Minotaur, a creature whose hybrid form suggests the tension between the human/civilized and the bestial/atavistic as well as the possibility that the unconscious may be a place of horrors rather than of healing. Whereas Doctor Y. shows his insensitivity to psyche by offhandedly minimizing the shadow/Minotaur's threat, Watkins wisely realizes that it can be "an old friend too," a source of wholeness and strength if it is properly integrated. However, having already realized a fellow-feeling with the shadowy rat-dogs and the atavistic apes, ${ }^{15}$ he writes what could be a stand-alone short story about the parachute drop into Yugoslavia and his love of Konstantina. In other words, shadow work seems to provide a foundation for anima work-in Jung's terms, the "apprentice-piece" precedes the "master-piece" (CW 9i, par. 61). But contrary to the implication of the banter about Ariadne and the Minotaur, Watkins has lurched ahead in relationships with women without having first done proper shadow work with other men, which is ironic because fighting Nazis and bonding with comrades provided many opportunities to do the first stage of the individuation process. Perhaps these wartime experiences were negated because Watkins on two occasions lost all his companions to enemy fire, much as Odysseus, to whom he is frequently compared, loses all his crewmen on the way home to Ithaca.

For Jung, there has been a departure (a dropping into the unconscious), a confrontation with the unconscious in dream/vision, and a return that finds him changed in fundamental ways. Now he resigns his academic position, transforms his visions into psychological theory, allows ideas to well up within him, approaches his clients more from the Self than from the ego, paints mandalas, and works with stone. In other words, he successfully brings his experience of the deep psyche into physical manifestation and himself into a more holistic orientation with everyday life. He achieves, as a result, the "true" sanity that Laing describes, which "entails in one way or another the dissolution of the normal ego, that false self competently adjusted to our alienated social reality; the emergence of the 'inner' archetypal mediators of divine power, and through this death a rebirth, and the eventual reestablishment of a new kind of ego-functioning, the ego now being the servant of the divine, no longer its betrayer" (Laing 101; emphasis added). Memories, Dreams, Reflections, then, appears significant to Lessing not only as a source of images that appear in Briefing but also for the pattern of successful nekyia that Jung's experiences establish. His concern with accessing and confronting unconscious material has its counterpoint in Lessing's depiction in Briefing of Watkins's lack of individuation. 


\section{Conclusion}

Following the electric shock therapy, Watkins informs his department chair that he will be able to deliver a series of lectures on The Iliad. Lecturing on The Odyssey would suggest that, like Odysseus in Ithaca, he remembers his nikyia. ${ }^{16}$ His subject, the everyday world of grinding toil and conflict, is appropriate because the Odyssean numinous is no longer available to him. In other words, Watkins does not live up to the standard of successful individuation that Memories, Dreams, Reflections sets out-a conscious life informed by memory of visionary experience. Returning to the status quo, he lacks the enlargement of personality that comes from within (CW 9i, par. 215) and does not achieve the "sacrifice of . . . egoistic aspirations and desires," a central theme of The Red Book (Drob 36). He is simply back where he began and is welcomed into the routine rationality of his former life, which caused his breakdown in the first place. All of the novel's hints with regard to a hero's journey of the mind and all its reminders of unity and harmony ultimately come to naught.

Briefing and Lessing's novella "The Temptation of Jack Orkney” are frequently considered companion pieces, but the endings differ significantly. Following the death of his father, Orkney begins having numinous dreams. Taking sleeping pills corresponds to Watkins's electric shock therapy, but Orkney's nekyia produces an alteration of personality in the third part of the hero's journey. His dream memory is not wiped clean. Instead, as the story concludes, the narrator states:

Now, in spite of everything, although he knew that fear would lie in wait there, his sleep had become another country, lying just behind his daytime one. Into that country he went nightly, with an alert, even if ironical interest - the irony was due to his habits of obedience to his pastfor a gift had been made to him. Behind the face of the sceptical [sic] world was another, which no conscious decision of his could stop him exploring. (308)

Just as Jung honors his visions and dreams by adjusting his everyday life, Orkney decides that he and his wife will move to Nigeria so that he can take a job that has been offered to him. "Spending two years in Africa would change them both, and they did not want to admit that they had become reluctant to change," says the narrator (307). Whereas Watkins simply returns to his former life, the Orkneys' temporary sacrifice of their comfortable life in England will lead to personal growth, perhaps through exposure to the positive connection to nature in Larson's experience of the river people in Africa. For the Orkneys, a change that Jung would approve of is on the horizon.

\section{Notes}

1. Witnessing the carnage, Watkins reaches what the accountant in Heart of Darkness calls "the very bottom of there" (Conrad 33), experiencing a nigredo or moment of despair: "Now I believed that everything was ended, and there was no hope anywhere for man or for the animals of the Earth” (85). Nigredo literally means blackness, which may have some connection to Nurse Black at the end of the novel. In addition, Nurse Black's name suggests black-and-white, either/or thinking rather than the inclusive both/and that Lessing favors. For example, it is Nurse Black who attempts to shut down Watkins's important conversation with Violet Stoke about alternative ways of knowing.

2. In the background is William Wordsworth's “Ode: Intimations of Immortality,” lines 67-68: "Shades of the prison-house begin to close / Upon the growing Boy.” Rosemary Baines’s letter specifically refers to "those 'prison shades”” (152). The Wordsworthian connection has been previously noted by Ruth Whittaker (81) and Paul Schlueter (120).

3. Nancy Shields Hardin, in "Doris Lessing and the Sufi Way,” emphasizes that for Lessing the physical world and the imaginal world are in a complementary (both/and) rather than a binary (either/or) relationship (571). Phyllis Sternberg Perrakis, in "Sufism, Jung and the Myth of the Kore: Revisionst Politics in Lessing’s Marriages,” discusses connections between the Jungian and Sufist background of Lessing’s work.

4. The following critics are of the same opinion: Joan Didion (193), Carole Klein (205), Roberta Rubenstein (Vision 88-89), Paul Schlueter (123), Michael Thorpe (31-32), and Virginia Tiger (88). Both Laing and Jung define "schizophrenia” etymologically. Laing states that it is a compound of "Schiz" (broken) and "Phrenos” (soul or heart) (90). Jung, following Bleuler, calls 


\section{Journal of Jungian Scholarly Studies}

\section{Vol. 11, No. 1, 2016}

schizophrenia a "split mind” ( $C W 3$, par. 497). To be schizophrenic means to be broken or divided in heart, mind, and soul.

5. The only monograph dealing exclusively with Lessing and Jung is Lorelei Cederstrom's Fine-Tuning the Feminine Psyche: Jungian Patters in the Novels of Doris Lessing." Jungian commentary can also be found in Douglas Bolling's "Structure and Theme in Briefing For A Descent Into Hell” (sic); Perrakis’s “Sufism, Jung, and the Myth of the Kore”; Mary Ann Singleton's The City and the Veld: The Fiction of Doris Lessing; Roberta Rubenstein's The Novelistic Vision of Doris Lessing: Breaking the Forms of Consciousness; and Ruth Whittaker's Doris Lessing.

6. The inserted capital letters are Rubenstein’s addition. A similar statement appears in Lessing's introduction to Idries Shah's Learning How To Learn: "But the 'discoveries' of Freud and Jung are to be found in Al Ghazzali and Ibu El Arabi, who died in the twelfth century, and in other great thinkers of the time. (Jung acknowledged his debt to the East. Is it not remarkable that his disciples are not curious about what else there might be?)” (n.p.).

7. Cederstrom erroneously considers the persona to be an archetype (10). As Jung wrote, "The persona is ... a functional complex that comes into existence for reasons of adaptation or personal convenience” ( $C W 6$, par. 801; emphasis added).

8. Lessing makes a similar statement in the preface to Shikasta: "Yes, I do believe that it is possible, and not only for novelists, to 'plug in' to an overmind, or Ur-mind, or unconscious, or what you will, and that this accounts for a great many improbabilities and 'coincidences"” (n.p.).

9. To begin with, these images are subtly built into the beginning of Watkins's vision. His drifting in the Atlantic is framed by a geographical quaternity: the Caribbean and Florida (northwest), Europe (northeast), Africa (southeast), and Brazil (southwest). Each hemisphere is itself a mandala or clock image. At first he drifts clockwise in the northern hemisphere (logos, time's forward march), then anti-clockwise in the southern (eros, a journey backward in time). Rubenstein states that anti-clockwise movement suggests movement backward in time (Vision 180). Logos and eros are my own suggestion. In addition, in Psychology and Alchemy (CW 12) Jung thinks of the world clock as a mandala. There are many other round or spherical objects in Briefing: a compass (10), flowers in one of the poems (19), the crystal disk, "this little bubble of Earth" (48), the sun and moon, the solar system (55), Earth’s biosphere seen from space (97, 99), an alarm clock (129), Baines’s mention that her "letter is like a snake swallowing its tail” (146), various references to webs, and the parachutes that lower Watkins and Bovey into Yugoslavia (202). Among these, flying saucer, snake, globe, and clock are mandala symbols in Jung's works. In particular, he identifies flying saucers as "manifestations of totality whose simple round form portrays the archetype of the self" as opposed to the ego ( $C W$ 10, par 622; 12, par. 126). Mandalas are thus symbols of transformation (such as the one Watkins undergoes when the Crystal finally takes him), for “Mandalas are birth-places, vessels of birth in the most literal sense” (CW 9i, par. 234).

10. See $C W 3$, par. 528: "the schizophrenic state of mind, so far as it yields archaic material, has all the characteristics of a 'big dream'-in other words, that it is an important event, exhibiting the same 'numinous' quality which in primitive cultures is attributed to a magic ritual.” In par. 549 Jung adds that big dreams are archetypal in the sense that their images are like those in mythology.

11. I am in accord here with Rubenstein's “Notes for Proteus: Doris Lessing Reads the Zeitgeist.” Rubenstein argues that Briefing and several other novels by Lessing are "instructive fables about life on this earth during our own era of relentless aggression and destruction” (14).

12. Doctors $\mathrm{X}$. and $\mathrm{Y}$. suggest the $\mathrm{X}$ and $\mathrm{Y}$ axes and thus a two-dimensional (limited) approach to treating mental disorder and a general indictment of scientific materialism. Since the axes form four quadrants that constitute a quaternity image, the doctors' names also suggest the wholeness that they seek to bring about in Watkins and the holism in medicine that they currently lack. There is also a Doctor Z., whose only letter to Doctor Y. appears roughly two-thirds of the way through the novel (171). It is Z. who initially prescribed Librium for Watkins's stammering (a drug that ironically does not liberate him). If a Z axis is added to $\mathrm{X}$ and $\mathrm{Y}$, one has the three axes of a sphere, another image of wholeness.

13. In brief, single vision involves scientific perception; twofold vision, intellectual/moral reflection; threefold vision, Jung's visionary mode; and fourfold vision, access to the spirit world via psychic functioning. The four types of vision appear in Blake's letter to Thomas Butts dated November 22, 1802 (Keynes 79). I discuss Blake's four categories of vision in my book The One Mind: C. G. Jung and the Future of Literary Criticism (195-204). 
14. Hillman's description of Jungian psychology as "thoroughly oppositional” (75) is somewhat reductive, for although oppositions such as anima/animus and conscious/unconscious are accurate descriptors, the goal of individuation, as Lessing understood, is a both/and synthesis of the unconscious and conscious awareness.

15. The apes and rat-dogs are one of the echoes of Jonathan Swift's Gulliver's Travels in Briefing. Thorpe states that the rat-dogs are "Yahoo-like creatures" (31), and Vlastos calls the setting they inhabit “a Swiftian land" (255). Comments about these creatures are actually descriptions of England and of world war, much as what Gulliver encounters reflects the England that he has left.

16. In The Collected Works Jung significantly misreads Odysseus's nekyia in book 11 of The Odyssey, referring to "the Descent into the Cave, the Nekyia" and adding in a footnote, "Cf. the passage in Odysseus' journey to Hades, where he meets his mother" (CW 5, par. 634, n. 26). Although Odysseus visits his dead mother and other shades, he does not descend into Hades. His descent is figurative, not literal. Jung uses a lighter touch in Psychology and Alchemy, considering nekyia the title of The Odyssey's book 11 and defining it as "the sacrifice to the dead for conjuring up the departed from Hades." The term "is therefore an apt designation for the 'journey to Hades,' the descent into the land of the dead.” Jung cites, as examples of nekyia, The Divine Comedy, Faust, and Christ's descent into hell in the Apocrypha (CW 12, par. 61, n. 2). Excerpts from this passage are one of the epigraphs in Hillman's study of Moby-Dick.

\section{Works Cited}

Bolling, Douglas. “Structure and Theme in Briefing For A Descent Into Hell.” Contemporary Literature 14.4 (1973): 550-64. JSTOR. Web. 1 June 2015.

Campbell, Joseph. The Hero with a Thousand Faces. Princeton: Princeton UP, 1949. Print.

Cederstrom, Lorelei. Fine-Tuning the Feminine Psyche: Jungian Patterns in the Novels of Doris Lessing. New York: Peter Lang, 1990. Print.

Conrad, Joseph. Heart of Darkness: A Case Study in Contemporary Criticism. Ed. Ross C. Murfin. New York: St. Martin’s, $1989,17-94$. Print.

Didion, Joan. “Review of Briefing for a Descent into Hell.” Sprague and Tiger 192-96.

Drob, Sanford L. Reading The Red Book: An Interpretive Guide to C. G. Jung’s Liber Novus. New Orleans: Spring Journal, 2012. Print. Edinger, Edward F. Melville’s Moby-Dick: An American Nekyia. Toronto: Inner City, 1995. Print.

Fike, Matthew A. The One Mind: C. G. Jung and the Future of Literary Criticism. New York: Routledge, 2014. Print.

Hardin. Nancy Shields. “Doris Lessing and the Sufi Way.” Contemporary Literature 14.4 (1973): 565-81. JSTOR. Web. 18 May 2015.

Hillman, James. The Dream and the Underworld. New York: Harper, 1979. Print.

Howe, Florence. “A Conversation with Doris Lessing (1966).” Contemporary Literature 14.4 (1973): 418-36. JSTOR. Web. 18 May 2015.

Jung, Carl. G. The Collected Works of C. G. Jung. Ed. Sir Herbert Read et al. Trans. R. F. C. Hull. 2nd ed. Princeton: Princeton UP, 1953-79. Print. 20 vols. Bollingen Ser. 20.

Memories, Dreams, Reflections. 1961. Ed. Aniela Jaffé. Trans. Richard and Clara Winston. Rev. ed. New York: Vintage, 1989. Print.

The Red Book: Liber Novus. Ed. Sonu Shamdasana. Trans. Mark Kyburz, John Peck, and Sonu Shamdasani. New York: Norton, 2009. Print.

Keynes, Geoffrey, ed. The Letters of William Blake. New York: Macmillan, 1956. Print.

Klein, Carole. Doris Lessing: A Biography. New York: Carrol \& Graf, 2000. Print.

Laing, R. D. The Politics of Experience. New York: Pantheon, 1967. Print.

Lessing, Doris. Briefing for a Descent into Hell. London: Jonathan Cape, 1971. Print.

Introduction. Learning How To Learn. By Idries Shah. San Francisco: Harper, 1981. N.p. Print. 
- Shikasta. New York: Knopf, 1979. Print.

—. “The Temptation of Jack Orkney.” The Temptation of Jack Orkney \& Other Stories New York: Knopf, 1972. 231-308. Print. . Under My Skin: Volume One of My Autobiography to 1949. New York: HarperCollins, 1994. Print. . Walking in the Shade: Volume Two of My Autobiography, 1949-1962. New York: HarperCollins, 1997. Print.

Perrakis, Phyllis Sternberg. “Sufism, Jung and the Myth of the Kore: Revisionist Politics in Lessing’s Marriages.” Mosaic: A Journal for the Interdisciplinary Study of Literature 25.3 (1992): 99-120. Print.

Rubenstein, Roberta. “Notes for Proteus: Doris Lessing Reads the Zeitgeist.” Doris Lessing: Interrogating the Times. Ed. Debrah Raschke, Phyllis Sternberg Perrakis, and Sandra Singer. Columbus: The Ohio State UP, 2010. 11-31. Print.

- The Novelistic Vision of Doris Lessing: Breaking the Forms of Consciousness. Urbana: U of Illinois P, 1979. Print.

Schlueter, Paul. The Novels of Doris Lessing. Carbondale: Southern Illinois UP, 1969. Print.

Singleton, Mary Ann. The City and the Veld: The Fiction of Doris Lessing. Lewisburg: Bucknell UP, 1977. Print.

Sprague, Claire, and Virginia Tiger, eds. Critical Essays on Doris Lessing. Boston: G. K. Hall, 1986. Print.

Thorpe, Michael. Doris Lessing. Ed. Ian Scott-Kilvert. London: F. Mildner \& Sons, 1973. Print.

Tiger, Virginia. ““Woman of Many Summers’: The Summer before the Dark.” Sprague and Tiger 86-94.

Van der Berk, Tjeu. Jung on Art: The Autonomy of the Creative Drive. New York: Routledge, 2012. Print.

Vlastos, Marion. “Doris Lessing and R. D. Laing: Psychopolitics and Prophecy.” PMLA 91.2 (1976): 245-58. JSTOR. Web. 15 June 2015.

Wordsworth, William. “Ode: Intimations of Immortality from Recollections of Early Childhood.” English Romantic Poets. Ed. David Perkins. 2nd ed. Fort Worth: Harcourt, 1995. Print.

Whittaker, Ruth. Doris Lessing. London: Macmillan, 1988. Print. 